\title{
Ex-vitro propagation of micropropagated sugarcane (Sacharum officinarum L.) genotypes using plant growth regulators IBA and BAP
}

\begin{abstract}
Ex-vitro propagation of micropropagated sugarcane plantlets of three selected sugarcane genotypes was carried out with the objective of evaluating their propagation responses to the interaction effects of BAP and IBA. Accordingly, six levels of IBA ( 0 , $\left.0.1,0.2,0.3,0.4 \& 0.5 \mathrm{mgL}^{-1}\right)$ and eight levels of $\operatorname{BAP}(0,0.75,1,1.25,1.5,1.75,2 \&$ $2.25 \mathrm{mgL}^{-1}$ ) with three sugarcane genotypes, each replicated three times were tested. The treatments were arranged in a factorial completely randomized design. Data on the number of tillers per shoot, average shoot length $(\mathrm{cm})$ and number of active leaves per shoot were collected twice every $30^{\text {th }}$ day after 30days of treatment application. Analysis of variance revealed that the interaction effects of BAP, IBA and the sugarcane genotypes was very highly significant $(\mathrm{P}<0.0001)$ on the number of tillers per shoot, average shoot length and number of active leaves per shoot. The optimum number of tillers per shoot (5.67), average shoot length $(40.77 \mathrm{~cm})$ and number of active leaves per shoot (6.97) were obtained at $0.1 \mathrm{mg} / 1 \mathrm{IBA}+0.75 \mathrm{mg} / 1 \mathrm{BAP}$ in C13281. In C86-56, the optimum number of tillers per shoot (4.50) was obtained at $0.1 \mathrm{mg} / 1$ IBA $+1.5 \mathrm{mg} / 1 \mathrm{BAP}$ while the maximum average shoot length $(48.33 \mathrm{~cm})$ and maximum number of active leaves per shoot (7.67) were obtained at $0.2 \mathrm{mg} / 1 \mathrm{IBA}+0.75 \mathrm{mg} / 1 \mathrm{BAP}$. In SP70-1284, the optimum number of tillers per shoot $(6.43)$ was obtained at $0.3 \mathrm{mg}$ / $1+1 \mathrm{mg} / 1$ BAP with $16.05 \mathrm{~cm}$ average shoot length and 4.87 active leaves per shoot. Thus, it can be deduced that production of an average of 5.5 plantlets per shoot within a month can be possible.
\end{abstract}

Keywords: ex-vitro propagation, sugarcane genotypes, C132-81, C86-56, SP701284 , micropropagated, meristematic
Volume 2 Issue 3 - 2017

\author{
Gezahegn Terefe,' Sunil TH,' Belay Tolera² \\ 'Department of Biology, Dilla University, Ethiopia \\ ${ }^{2}$ Ethiopian Sugar Corporation, Ethiopia
}

\begin{abstract}
Correspondence: Belay Tolera, Ethiopian Sugar Corporation, Research and Development Center, variety Improvement Research Program, Biotechnology Research Team, Wonji Research and Development Center,Wonji, Ethiopia, Fax+25I222200144, Tel +251-910181644, Email belaytolera@yahoo.com
\end{abstract}

Received: January 10, 2017 | Published: February 27, 2017
Abbreviations: BAP, 6-benzylaminopurine; REGWQ, ryan-einot-gabriel- welsch; IBA, indole-3-butyric acid; IVPT, in-vitro propagation technology; DF, degree of freedom

\section{Introduction}

Sugarcane is a perennial grass which produces seed under suitable conditions, but for commercial production, it is propagated from stalk cuttings. Propagation through stalk cuttings is the traditional method of sugarcane propagation in which stalk cuttings containing one or more buds, termed sets are used for commercial planting. ${ }^{1}$ The Ethiopian Sugar Industry used this traditional method of propagation alone for the last 50 years till 2012. However, under the new plan of the Industry to expand the existing farms and establishment of vast sugarcane plantation projects with many high crushing capacity sugar factories, the tradition propagation method alone was seen to have various draw backs. Among these, availability of enough amount of quality disease free planting material within short time, transport of bulky unclean seed cane from existing farms to the remote project farms, the low rate of propagation (usually 1:10), lack of methods for fast commercialization of improved and adapted varieties, obsolation of productive commercial varieties due to disease, lack of alternative techniques for rejuvenation and disease cleansing of the old contaminated sugarcane varieties were the major limitations identified as challenges to the vast expansion and new development plans. $^{2-3}$ With a view to minimize the challenges, microproagation technology was adopted and implemented to supplement the tradition method of sugarcane propagation in all sugar estates and projects. Microproagation Technology is a technique through which group of genetically identical plants all derived from a selected individual multiply vegetatively and rapidly by aseptic culture of meristematic regions under defined nutritional and controlled environmental conditions in vitro. ${ }^{4}$

Nowadays, unlike the traditional propagation method, it is the only practical means of achieving rapid and large scale production of disease free quality planting materials in sugarcane $e^{5-7}$ and alternative approach for fast multiplication of a genotype in its original form. It is very effective in entire disease cleansing, rejuvenation and subsequent mass propagation of well adapted and promising varieties facing gradual deterioration in yield, quality and vigor due to accumulation of pathogens during prolonged vegetative cultivation and hence sustains the productive potential of sugarcane crops for a longer period $^{8-9}$ Furthermore, micropropagated sugarcane plants were reported to give superior in cane and sugar yield as compared to their donors under similar agronomic management systems. ${ }^{10-14}$ However, the Ethiopian Sugar Corporation is procuring the micropropagated sugarcane plantlets from different organizations where the cost of procurement is high (about US\$ 0.205 per plantlet). The erratic supply, long distance transport of the delicate plantlets followed by reduced survival, the increasing demand of micropropagated plants with the subsequent procurement cost increment were found to be the major limitations for the profitability and sustainability of the microproagation technology. Therefore, this experiment was carried 
out with the objective to evaluate the effects of 6-benzylaminopurine (BAP) in vivo propagation of tissue culture raised sugarcane plantlets of three sugarcane genotypes (C132-81; C86-56 \& SP70-1284) with a view to complement microproagation technology and to ensure continuous supply, cut down the cost of plantlets procurement and propagation of sufficient amount of quality planting materials at the farm gate nursery within short period of time.

\section{Materials and methods}

\section{Study site}

The study was carried out at Metahara sugarcane plantation, located at Eastern part of the country, at about $200 \mathrm{~km}$ away from the capital, Addis Ababa, Ethiopia. Metahara Sugar estate is situated at $8^{0}$ $53^{\prime} \mathrm{N}$ latitude and $39^{\circ} 52^{\prime} \mathrm{E}$ longitudes at an altitude of 950mas with a semi arid climatic condition.

\section{Sources of planting materials}

The experimental materials were in vitro propagated sugarcane genotypes of C132-81, C86-56 and SP70-1284. The primary acclimatized plantlets of these sugarcane genotypes were delivered with intact coco-peat from Mekelle Technology Institute Tissue Culture Laboratory and directly planted in white polyethylene bag ( $8 \mathrm{~cm}$ diameter with $10 \mathrm{~cm}$ height) filled with mixture of Luvisol, sand and compost in the ratio of $8: 2: 1$.

\section{Experimental Design and treatments}

The experimental design was Completely Randomized Design with factorial treatment combination arrangements. Three sugarcane genotypes (C132-81,C86-56 and SP70-1284) with six levels of IBA $\left(0,0.1,0.2,0.3,0.4\right.$ and $\left.0.5 \mathrm{mgL}^{-1}\right)$ and eight levels of $\operatorname{BAP}(0,0.75$, $1,1.25,1.5,1.75,2$ and $\left.2.25 \mathrm{mgL}^{-1}\right)$ resulting in $3^{*} 6 * 8=144$ treatment combination arrangements each replicated three times. Each plot contains 30 pots (one plantlet per pot).

\section{Data collection}

Data on the number of tillers per shoot shoot length and number of active leaves per shoot was collected from ten randomly selected plantlets at $30^{\text {th }}$ and $60^{\text {th }}$ days of treatment application.

\section{Data analysis}

The collected data were compiled and an average of the data was subjected to analysis of variance using SAS software version 9.1.3 while separation of significant means' was done using REGWQ (Ryan-Einot-Gabriel- Welsch) Multiple Range Test.

\section{Result and discussion}

Analysis of variance revealed that the interaction of Indole-3-butyric acid (IBA), 6-benzylaminopurine (BAP) and sugarcane genotype have a very highly significant $(B A P * I B A *$ Genotype $=p<0.001)$ effect on all the response variables tested: numbers of leaves per shoot, average shoot length and number of leaves per shoot in all the sugarcane genotypes tested: C132-81, C86-56 and SP70-1284 (Appendix 1).

Comparison of the sugarcane genotypes revealed that all the three sugarcane genotypes showed marked variation in all the responses tested: number of tillers per shoot, average shoot length and number of leaves per shoot (Appendix 2). Regardless of the other treatments, comparison of the sugarcane genotypes showed that SP70-1284 produced the highest number of tillers per shoot while C86-56 gave the highest average shoot length $(37.28 \mathrm{~cm})$ and maximum number of active leaves (6.36) per shoot (Appendix 2). In sugarcane genotype C132-81, the lowest number of tillers per shoot (1.63) was found on $0 \mathrm{mg} / 1 \mathrm{IBA}+0 \mathrm{mg} / 1$ BAP (control treatment) with $27.27 \mathrm{~cm}$ average shoot length and 4.00 leaves per shoot (Table 1). However, increasing the concentration of IBA from $0 \mathrm{mg} / 1$ to $0.1 \mathrm{mg} / 1$ and BAP from $0 \mathrm{mg} / 1$ to $0.75 \mathrm{mg} / 1$, increased the number of tillers per shoot from 1.63 to 5.67 , average shoot length from $27.72 \mathrm{~cm}$ to $40.77 \mathrm{~cm}$ and number of leaves from 4.00 to 6.97 . The maximum number of tillers per shoot (5.67), highest average shoot length $(40.77 \mathrm{~cm})$ and number of leaves per shoot (6.97) was obtained at $0.1 \mathrm{mg} / 1 \mathrm{IBA}$ and $0.75 \mathrm{mg} / 1 \mathrm{BAP}$ in sugarcane genotype C132-81 (Table 1). Holding the concentration of BAP at $0.75 \mathrm{mg} / 1$ and increasing the concentration of IBA beyond $0.1 \mathrm{mg} / 1$ up to $0.5 \mathrm{mg} / 1$ showed a declining trend in number of tillers per shoot, average shoot length $(\mathrm{cm})$ and number of leaves per shoot.

Table I Interaction effects of IBA and BAP on ex-vitro multiplication of sugarcane genotype CI32-8I.

\begin{tabular}{|c|c|c|c|c|}
\hline \multicolumn{2}{|c|}{ PGRs(mg/l) } & \multicolumn{3}{|l|}{$C|32-8|$} \\
\hline \multicolumn{2}{|c|}{$\begin{array}{l}\text { Plant growth regulators (mg/l/ } \\
\text { plot) }\end{array}$} & \multirow{2}{*}{$\begin{array}{l}\text { Number of tillers per } \\
\text { shoot }\end{array}$} & \multirow{2}{*}{$\begin{array}{l}\text { Average shoot } \\
\text { length }(\mathrm{cm})\end{array}$} & \multirow{2}{*}{$\begin{array}{l}\text { Number of active leaves per } \\
\text { shoot }\end{array}$} \\
\hline IBA & BAP & & & \\
\hline 0 & 0 & $1.63^{z}$ & $27.27^{w}$ & $4.00^{e}$ \\
\hline 0.1 & 0.75 & $5.67^{c}$ & $40.77^{w}$ & $6.97^{\mathrm{ab}}$ \\
\hline 0.2 & 0.75 & $3.20^{\circ \mathrm{p}}$ & $36.87^{k}$ & $6.80^{\mathrm{b}}$ \\
\hline 0.3 & 0.75 & $2.80^{\mathrm{i}}$ & $30.50^{\mathrm{s}}$ & $5.90^{c}$ \\
\hline 0.4 & 0.75 & $2.70^{t}$ & $29.67^{t}$ & $5.17^{f}$ \\
\hline 0.5 & 0.75 & $2.63^{v}$ & $29.03^{u}$ & $4.93^{f g}$ \\
\hline 0.1 & I & $2.60^{\mathrm{jk}}$ & $36.80^{k}$ & $6.03^{c}$ \\
\hline 0.2 & 1 & $2.60^{\mathrm{jk}}$ & $34.40^{n}$ & $6.47^{b}$ \\
\hline 0.3 & 1 & $3.73^{k}$ & $29.13^{u}$ & $6.23^{b c}$ \\
\hline
\end{tabular}


Table Continued..

\begin{tabular}{|c|c|c|c|c|}
\hline \multicolumn{2}{|c|}{ PGRs(mg/l) } & \multicolumn{3}{|l|}{$C|32-8|$} \\
\hline \multicolumn{2}{|c|}{$\begin{array}{l}\text { Plant growth regulators }(\mathrm{mg} / \mathrm{ll} \\
\text { plot) }\end{array}$} & \multirow{2}{*}{$\begin{array}{l}\text { Number of tillers per } \\
\text { shoot }\end{array}$} & \multirow{2}{*}{$\begin{array}{l}\text { Average shoot } \\
\text { length }(\mathrm{cm})\end{array}$} & \multirow{2}{*}{$\begin{array}{l}\text { Number of active leaves per } \\
\text { shoot }\end{array}$} \\
\hline IBA & BAP & & & \\
\hline 0.4 & I & $3.53^{\prime}$ & $27.07^{w}$ & $6.13^{\mathrm{bc}}$ \\
\hline 0.5 & I & $3.20^{\circ \mathrm{p}}$ & $27.00^{w}$ & $6.00^{\circ}$ \\
\hline 0.1 & 1.25 & $2.43^{x}$ & $27.33^{w}$ & $5.87^{c}$ \\
\hline 0.2 & 1.25 & $2.40^{x}$ & $27.50^{\vee}$ & $5.90^{\circ}$ \\
\hline 0.3 & 1.25 & $2.93^{\mathrm{s}}$ & $33.17^{\circ}$ & $6.00^{c}$ \\
\hline 0.4 & 1.25 & $3.07^{9}$ & $35.73^{i}$ & $6.63^{\mathrm{b}}$ \\
\hline 0.5 & 1.25 & $3.43^{n}$ & $36.27^{\mathrm{k}}$ & $6.40^{\mathrm{b}}$ \\
\hline 0.1 & 1.5 & $2.87^{\mathrm{s}}$ & $34.60^{\mathrm{m}}$ & $6.03^{c}$ \\
\hline 0.2 & 1.5 & $2.93^{r}$ & $27.77^{w}$ & $6.10^{\mathrm{bc}}$ \\
\hline 0.3 & 1.5 & $2.57^{v}$ & $28.30^{4}$ & $6.27^{\mathrm{bc}}$ \\
\hline 0.4 & 1.5 & $2.60^{v}$ & $33.53^{n}$ & $5.80^{\circ}$ \\
\hline 0.5 & 1.5 & $2.77^{\mathrm{t}}$ & $35.27^{n}$ & $5.53^{d}$ \\
\hline 0.1 & 1.75 & $4.00^{\circ}$ & $37.40^{\mathrm{j}}$ & $6.60^{\mathrm{b}}$ \\
\hline 0.2 & 1.75 & $3.00^{r}$ & $32.67 \mathrm{P}$ & $6.13^{b c}$ \\
\hline 0.3 & 1.75 & $3.00^{r}$ & $32.90^{\circ}$ & $6.33^{\mathrm{bc}}$ \\
\hline 0.4 & 1.75 & $2.70^{u}$ & $28.53^{u}$ & $6.27^{\mathrm{bc}}$ \\
\hline 0.5 & 1.75 & $2.20^{y}$ & $27.27^{\mathrm{w}}$ & $5.80^{\circ}$ \\
\hline 0.1 & 2 & $2.53^{w}$ & $32.20^{9}$ & $5.70^{c d}$ \\
\hline 0.2 & 2 & $2.87^{\mathrm{t}}$ & $38.20^{i}$ & $5.93^{c}$ \\
\hline 0.3 & 2 & $3.17^{\circ \mathrm{P}}$ & $32.53^{9}$ & $6.27^{\mathrm{bc}}$ \\
\hline 0.4 & 2 & $3.20^{\circ \mathrm{p}}$ & $26.73^{w}$ & $5.97^{\mathrm{cd}}$ \\
\hline 0.5 & 2 & $2.83^{t}$ & $37.73^{i}$ & $6.50^{b}$ \\
\hline 0.1 & 2.25 & $2.23^{y}$ & $33.17^{\circ}$ & $5.50^{d}$ \\
\hline 0.2 & 2.25 & $2.10^{y}$ & $34.33^{n}$ & $5.60^{c}$ \\
\hline 0.3 & 2.25 & $2.47^{w}$ & $31.67^{\mathrm{s}}$ & $5.87^{c}$ \\
\hline 0.4 & 2.25 & $2.97^{r}$ & $30.77^{\mathrm{s}}$ & $4.03^{\mathrm{ab}}$ \\
\hline 0.5 & 2.25 & $2.40^{\mathrm{w}}$ & $30.67^{\mathrm{s}}$ & $3.60^{\mathrm{cd}}$ \\
\hline $\mathrm{CV}$ & & 7.6 & 12.7 & 6.6 \\
\hline Mean \pm SE & & 0.36 & 2.45 & 0.22 \\
\hline
\end{tabular}

Values (Mean \pm SE) in the table indicate superscripts with the same letter are not significantly different.

Similarly, at $1 \mathrm{mg} / \mathrm{l} \mathrm{BAP,} \mathrm{increasing} \mathrm{the} \mathrm{concentration} \mathrm{of} \mathrm{IBA}$ from 0.1 up to $0.3 \mathrm{mg} / 1$ showed an increasing trend in the number of tillers per shoot and number of leaves per shoot while further increase revealed a decreasing effect in both response variables (Table 1). For the response variable shoot length, increasing the concentrations of IBA from 0.1 up to 0.5 at $1 \mathrm{mg} / 1$ BAP showed a decreasing effect. Generally, for in vivo proliferation of sugarcane genotype C132-81, $0.1 \mathrm{mg} / 1 \mathrm{IBA}$ with $0.75 \mathrm{mg} / 1 \mathrm{BAP}$ give the optimum growth response for number of tillers per shoot, average shoot length $(\mathrm{cm})$ and number of leaves per shoot. Further increase in either of the growth regulators or both has no any biological and economic advantage (Table 1). In sugarcane genotype C86-56, the lowest number of tillers per shoot $(1.50)$ and average shoot length $(22.67 \mathrm{~cm})$ was found on the control treatment $(0 \mathrm{mg} / 1 \mathrm{IBA}$ and BAP) while the lowest number of leaves per shoot (4.10) was obtained at $0.5 \mathrm{mg} / 1 \mathrm{IBA}$ and $2.25 \mathrm{mg} / 1$ BAP (Table 2). In C86-56, increase in the number of tillers per shoot from 1.50 to 2.67 ; average shoot length from $22.67 \mathrm{~cm}$ to 34.00 $\mathrm{cm}$ and number of leaves per shoot from 4.70 to 7.00 was obtained as a result of $0.1 \mathrm{mg} / 1 \mathrm{IBA}+0.75 \mathrm{mg} / \mathrm{l}$ BAP (Table 2). At $0.75 \mathrm{mg} / 1$ BAP, increasing the concentration of IBA from $0.1 \mathrm{mg} / 1$ to $0.2 \mathrm{mg} / 1$, increased the number of tillers per shoot, average shoot length and number of leaves per shoot from 2.67 to $33,34 \mathrm{~cm}$ to $42 \mathrm{~cm}$ and 7.00 to 7.67 , respectively. 
Table 2 Interaction effects of IBA and BAP on ex-vitro multiplication of sugarcane genotype C86-56

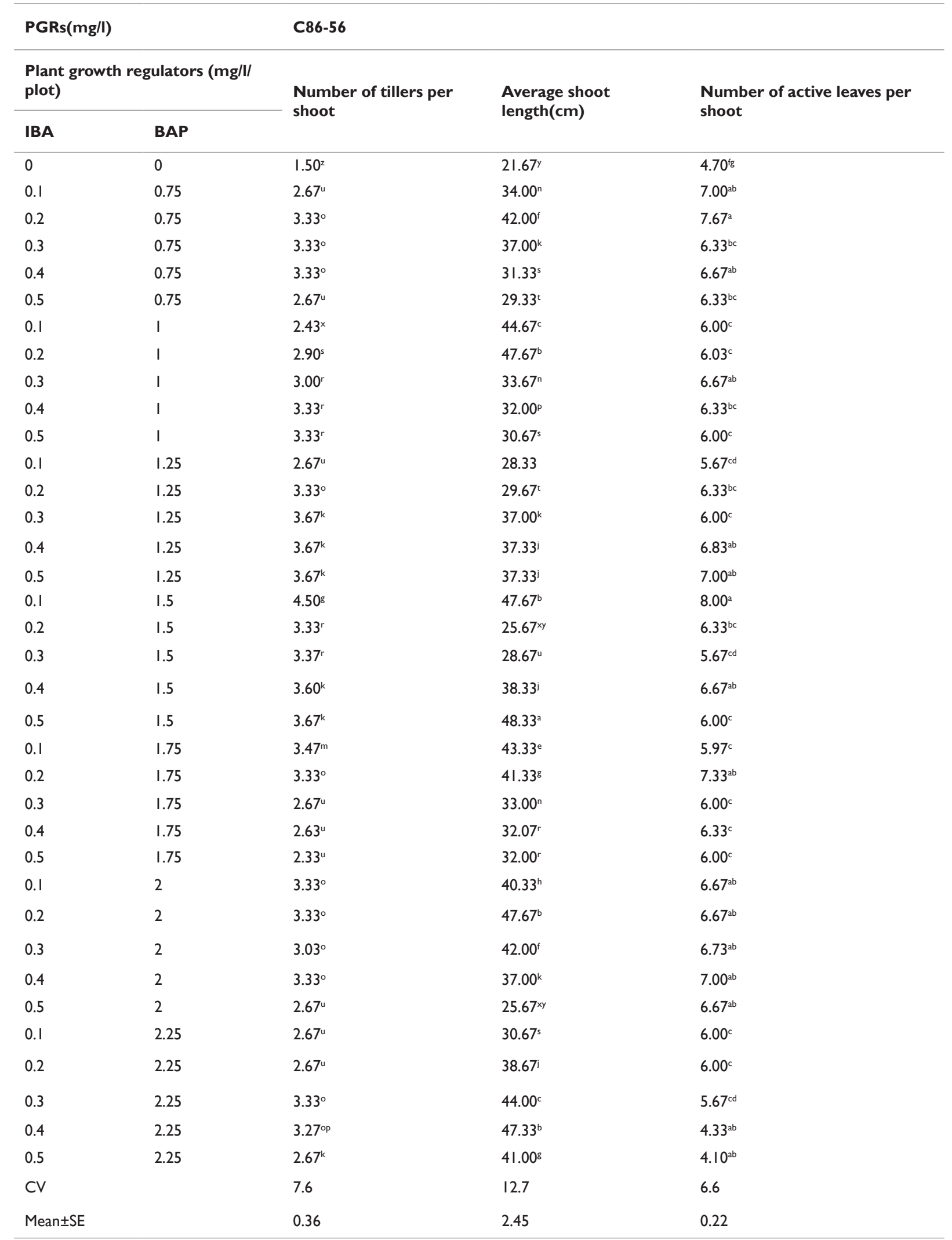

Values (Mean \pm SE) in the table indicate superscripts with the same letter are not significantly different 
However, further increase in the concentration of IBA at $0.75 \mathrm{mg} / 1$ BAP has no positive effect on neither of the response variables (number of tillers per shoot, average shoot length and number of leaves per shoot) tested. For this genotype (C86-56), the maximum number of tillers per shoot (4.50) was obtained at $0.1 \mathrm{mg} / 1 \mathrm{IBA}+1.5 \mathrm{mg} / 1 \mathrm{BAP}$ while the highest average shoot length $(48.33 \mathrm{~cm})$ and maximum number of leaves per shoot (7.67) was obtained at $0.5 \mathrm{mg} / 1 \mathrm{IBA}+1.5 \mathrm{mg} / 1 \mathrm{BAP}$ and $0.2 \mathrm{mg} / 1 \mathrm{IBA}+0.75 \mathrm{mg} / \mathrm{l} \mathrm{BAP}$, respectively. In sugarcane genotype SP70-1284, the lowest number of tillers per shoots (2.50) was obtained on the control treatment $(0 \mathrm{mg} / 1 \mathrm{IBA}+0 \mathrm{mg} / \mathrm{l} \mathrm{BAP})$ while the maximum number of tillers per shoot (6.43) was obtained at $0.3 \mathrm{mg} / 1$ IBA along with $1.0 \mathrm{mg} / 1 \mathrm{BAP}$ with $16.05 \mathrm{~cm}$ average shoot length and 4.87 leaves per shoot (Table 3). At $1.0 \mathrm{mg} / 1 \mathrm{BAP}$, further increase in the

Table 3 Interaction effects of IBA and BAP on ex-vitro multiplication of sugarcane genotype SP70-I 284

\begin{tabular}{|c|c|c|c|c|}
\hline \multicolumn{2}{|c|}{ PGRs(mg/l) } & \multicolumn{3}{|l|}{ SP70 - I 284} \\
\hline \multicolumn{2}{|c|}{$\begin{array}{l}\text { Plant growth regulators }(\mathrm{mg} / \mathrm{l} / \\
\text { plot) }\end{array}$} & \multirow{2}{*}{$\begin{array}{l}\text { Number of tillers/ } \\
\text { shoot }\end{array}$} & \multirow{2}{*}{$\begin{array}{l}\text { Average shoot } \\
\text { length }(\mathrm{cm})\end{array}$} & \multirow{2}{*}{$\begin{array}{l}\text { Number of active leaves/ } \\
\text { Shoot }\end{array}$} \\
\hline IBA & BAP & & & \\
\hline 0 & 0 & $2.50^{\mathrm{w}}$ & $26.33^{x}$ & $6.00^{c}$ \\
\hline 0.1 & 0.75 & $5.63^{c}$ & $29.23^{\mathrm{t}}$ & $5.13^{f}$ \\
\hline 0.2 & 0.75 & $4.53^{8}$ & $31.13^{\mathrm{s}}$ & $5.40^{\mathrm{e}}$ \\
\hline 0.3 & 0.75 & $3.67^{\mathrm{k}}$ & $25.83^{x}$ & $5.60^{d}$ \\
\hline 0.4 & 0.75 & $4.10^{\circ}$ & $26.57^{x}$ & $5.73^{\mathrm{cd}}$ \\
\hline 0.5 & 0.75 & $3.73^{\mathrm{k}}$ & $29.60^{\mathrm{t}}$ & $5.13^{f}$ \\
\hline 0.1 & I & $3.23^{\circ}$ & $41.30^{\mathrm{g}}$ & $5.07^{f}$ \\
\hline 0.2 & 1 & $3.70^{k}$ & $32.50^{r}$ & $4.83^{\text {fg }}$ \\
\hline 0.3 & I & $6.43^{\mathrm{a}}$ & $16.05^{z}$ & $4.87^{\mathrm{fg}}$ \\
\hline 0.4 & I & $5.57^{\mathrm{d}}$ & $37.80^{i}$ & $5.23^{f}$ \\
\hline 0.5 & I & $4.90^{\text {ef }}$ & $26.70^{x}$ & $5.53^{\mathrm{cd}}$ \\
\hline 0.1 & 1.25 & $4.07^{i}$ & $25.40^{y}$ & $5.13^{f}$ \\
\hline 0.2 & 1.25 & $4.00^{\circ}$ & $29.40^{\mathrm{t}}$ & $5.17^{f}$ \\
\hline 0.3 & 1.25 & $4.13^{i}$ & $41.30^{\mathrm{g}}$ & $5.07^{f}$ \\
\hline 0.4 & 1.25 & $4.13^{i}$ & $34.17^{n}$ & $4.97^{f}$ \\
\hline 0.5 & 1.25 & $5.33^{e}$ & $24.67^{x y}$ & $5.00^{f g}$ \\
\hline 0.1 & 1.5 & $5.73^{\mathrm{b}}$ & $24.60^{x y}$ & $5.27^{f}$ \\
\hline 0.2 & 1.5 & $4.03^{i}$ & $25.97 y$ & $5.57^{\mathrm{vd}}$ \\
\hline 0.3 & 1.5 & $4.33^{\mathrm{h}}$ & $26.73^{x}$ & $5.67^{d}$ \\
\hline 0.4 & 1.5 & $4.37^{\mathrm{h}}$ & 37.47 & $4.93^{\text {fg }}$ \\
\hline 0.5 & 1.5 & $4.33^{\mathrm{h}}$ & $37.67 i$ & $5.00^{f}$ \\
\hline 0.1 & 1.75 & $4.37^{\mathrm{h}}$ & $31.33^{\mathrm{s}}$ & $5.00^{f}$ \\
\hline 0.2 & 1.75 & $5.67^{d}$ & $26.33^{\mathrm{s}}$ & $5.00^{f}$ \\
\hline 0.3 & 1.75 & $5.00^{\mathrm{e}}$ & $26.40^{\mathrm{s}}$ & $5.27^{f}$ \\
\hline 0.4 & 1.75 & $3.83^{i}$ & $24.00^{x y}$ & $5.50^{\mathrm{cd}}$ \\
\hline 0.5 & 1.75 & $3.57^{1}$ & $22.60^{y}$ & $5.10^{\mathrm{fg}}$ \\
\hline 0.1 & 2 & $4.53^{8}$ & $36.90^{k}$ & $4.87^{\mathrm{fg}}$ \\
\hline 0.2 & 2 & $4.00^{\circ}$ & $39.80^{\circ}$ & $5.37^{f}$ \\
\hline
\end{tabular}

concentration of BAP from $0.3 \mathrm{mg} / 1$ to $0.4 \mathrm{mg} / 1$ decreased the number of tillers per shoot from 6.43 to 5.57 (Table 3 ). The rate of sugarcane propagules multiplication depends upon auxin - cytokinine balance. ${ }^{11}$ A low concentration of auxin is often beneficial in conjunction with higher levels of cytokinine during shoot multiplication and exogenous auxin does not promote auxiliary shoot proliferation; however, their presence in growth medium may improve the plant growth. Although cytokinines are known to stimulate cell division, but does not induce DNA synthesis. Nevertheless, the presence of auxin promotes DNA synthesis. Hence, the presence of auxin together with Cytokinine stimulates cell division and control morphogenesis thereby influences shoot multiplication. ${ }^{2-3}$ 
Table Continued..

\begin{tabular}{|c|c|c|c|c|}
\hline \multicolumn{2}{|c|}{ PGRs(mg/l) } & \multicolumn{3}{|l|}{ SP70 - | 284} \\
\hline \multicolumn{2}{|c|}{$\begin{array}{l}\text { Plant growth regulators (mg/l/ } \\
\text { plot) }\end{array}$} & \multirow{2}{*}{$\begin{array}{l}\text { Number of tillers/ } \\
\text { shoot }\end{array}$} & \multirow{2}{*}{$\begin{array}{l}\text { Average shoot } \\
\text { length }(\mathrm{cm})\end{array}$} & \multirow{2}{*}{$\begin{array}{l}\text { Number of active leaves/ } \\
\text { Shoot }\end{array}$} \\
\hline IBA & BAP & & & \\
\hline 0.3 & 2 & $3.60^{k}$ & $31.63^{\mathrm{s}}$ & $4.93^{f g}$ \\
\hline 0.4 & 2 & $3.57^{\mathrm{kl}}$ & $22.93^{y}$ & $4.90^{\mathrm{fg}}$ \\
\hline 0.5 & 2 & $3.10^{r}$ & $22.60 y$ & $5.60^{\mathrm{cd}}$ \\
\hline 0.1 & 2.25 & $4.03^{i}$ & $26.30^{x}$ & $5.30^{d}$ \\
\hline 0.2 & 2.25 & $4.47^{8}$ & $28.70^{v}$ & $4.87^{f g}$ \\
\hline 0.3 & 2.25 & $4.60^{f}$ & $39.83^{i}$ & $4.97^{\mathrm{fg}}$ \\
\hline 0.4 & 2.25 & $4.17^{i}$ & $39.67^{i}$ & $5.03^{f g}$ \\
\hline 0.5 & 2.25 & $4.00^{i}$ & $26.27^{x}$ & $5.73^{\mathrm{cd}}$ \\
\hline $\mathrm{CV}$ & & 7.6 & 12.7 & 6.6 \\
\hline Mean & & 0.36 & 2.45 & 0.22 \\
\hline
\end{tabular}

Values (Mean \pm SE) in the table indicate superscripts with the same letter are not significantly different.

Appendix I Summary for ANOVA on the interaction effects of BAP, IBA and sugarcane genotypes

\begin{tabular}{|c|c|c|c|c|}
\hline \multirow{2}{*}{ Source of variation } & \multirow{2}{*}{ DF } & \multicolumn{3}{|l|}{ Mean square } \\
\hline & & Number of tillers/shoot & Average Shoot length(cm) & Number of leaves/shoot \\
\hline IBA & 4 & $1.05^{*}$ & $43.08^{*}$ & $0.54 * *$ \\
\hline BAP & 6 & $2.82 * * *$ & $709.77 * * *$ & $1.89 * * *$ \\
\hline IBA*BAP & 24 & $1.11 * * *$ & $71.49 * * *$ & $0.43^{* * *}$ \\
\hline Gen & 2 & $45.34 * * *$ & $1110.21 * * *$ & $24.17 * * *$ \\
\hline IBA*Gen & 8 & $0.83^{*}$ & $16.36 \mathrm{~ns}$ & $0.12 \mathrm{~ns}$ \\
\hline BAP*Gen & 12 & $2.26 * * *$ & $142.78^{* * * *}$ & $0.98 * * *$ \\
\hline IBA*BAP*Gen & 48 & $2.64 * * *$ & $30.31 * * *$ & $1.36 * * *$ \\
\hline
\end{tabular}

Remark: $\mathrm{P} \leq 0.000 \mathrm{I}=* * * ; \mathrm{P}>0.000 \mathrm{I}$ and $\mathrm{P}<0.00 \mathrm{I}=* * \mathrm{P}>0.00 \mathrm{I}$ and $\mathrm{P}<0.05=* ; \mathrm{P}>0.05=\mathrm{ns}$

Appendix 2 Comparison of sugarcane genotypes to the interaction effects of IBA, BAP and Sugarcane genotypes

\begin{tabular}{llll}
\hline Genotype & Number of tillers/shoot & Average shoot length(cm) & Number of leaves/shoot \\
\hline C86-56 & $3.02 \mathrm{c}$ & $37.28 \mathrm{a}$ & $6.36 \mathrm{a}$ \\
CI32-8I & $3.20 \mathrm{~b}$ & $32.94 \mathrm{~b}$ & $6.14 \mathrm{~b}$ \\
SP70-1284 & $4.45 \mathrm{a}$ & $30.13 \mathrm{c}$ & $5.19 \mathrm{c}$ \\
\hline
\end{tabular}

Remark: Letters with the same letter are not significantly different

\section{Conclusion}

The conventional method of sugarcane planting material propagation has many limitations while microproagation technology is efficient to solve all the limitations, However continuous and sustainable supply of micropropagated plants is erratic and unreliable besides the costly production or procurement cost challenging the use of the technology. Hence, In-vitro propagation technology (IVPT) was developed to complement tissue culture technology, but reproducibility of the IVPT protocols is dependent on the genotype, environmental weather conditions, soil types and mixture (ratios) used, plant growth regulators types and concentrations and interaction of the factors used. Therefore, the aim of this study was to optimize ex-vitro propagation protocol for three recently released sugar genotypes: C132-81, C86-56 and SP70-1284 using IBA and BAP. The result proved that Ex-vitro propagation of the sugarcane genotypes tested is highly dependent on the interaction effects of IBA, BAP and the sugarcane genotypes. Treatment combination containing $0.1 \mathrm{mg} / 1$ $\mathrm{IBA}+0.75 \mathrm{mg} / \mathrm{l} \mathrm{BAP}$ for $\mathrm{C} 132-81,0.1 \mathrm{mg} / 1 \mathrm{IBA}+1.5 \mathrm{mg} / 1 \mathrm{BAP}$ for C86-56 and $0.3 \mathrm{mg} / 1 \mathrm{IBA}+1.0 \mathrm{mg} / 1 \mathrm{BAP}$ for SP70-1284 were found to give the optimum ex-vitro proliferation responses. Thus, from this result, it can be deduced that this result can be used to produce sufficient quantity ( 5.5 plantlets per shoot within a month) of quality planting materials and therefore can guarantee sustainable supply of planting materials with the lowest possible cost (possible to produce a plantlet with US\$ 0.05 against the procurement cost of US\$ 0.225 per plantlet). 


\section{Acknowledgements}

None.

\section{Conflict of interest}

The author declares no conflict of interest.

\section{References}

1. Ridge R. IPI Bulletin No. 21: Fertilizing for High Yield and Quality-Sugarcane. Australia: IPI Publications; 2013. 117 p.

2. Tolera B. In Vivo Proliferation of In Vitro propagated sugarcane (Saccharum officinarum L.) genotypes at Tana-beles sugar development project, North-Western Ethiopia. Cell Dev Biol. 2015;4:161.

3. Tolera B, Diro M, Belew D. Response of Sugarcane (Sacharum officinarum L.) Varieties to BAP and IAA on In vitro Shoot multiplication. Adv Crop Sci Tech. 2014;2:126.

4. Ahloowalia BS, Prakash J, Savangikar VA, et al. Low cost options for tissue culture technology in developing countries: proceedings of a technical meeting organized by the joint FAO/IAEA division of nuclear techniques in food and agriculture and held in Vienna 26-30 August 2002. Austria: Vienna : International Atomic Energy Agency; 2002. 106 p.

5. Lal N, Krishna R. Sugarcane and its problems: Tissue culture for pure and disease free seed production in sugarcane. Indian sugar. 1994;44:847-848.

6. Lorenzo JC, Ojeda E, Espinosa A, et al. Field performance of temporary immersion bioreactor derived sugarcane Plants. In Vitro Cell Dev Biol Plant. 2001;37(6):803-806.
7. Krishnamurthi M, Tlaskal J. Fiji disease resistant: Saccharum officinarum L.var. Pindar sub clone from tissue culture. Proc ISSCT. 1994;13:130-137.

8. Sreenivasan TV, Sreenivasan J. Microproagation of sugarcane varieties for increasing cane yield. SISSTA sugar J. 1992;18:61-64.

9. Anonymous. Microproagation: A Tissue culture technique in sugarcane. India: Indian Institute of sugarcane Research; 2002.

10. Ibrahim M, Tolera B, Aman J, et al. Evaluation of Tissue culture raised sugarcane planting materials against their donor conventional seed sources as initial sources of seed cane at Tendaho sugar development project, North-Eastern Ethiopia. J Hortic. 2016;3:168.

11. Sood N, Kumar Gupta P, Srivastava RK, et al. Comparative studies on field performance of micropropagated and Conventionally propagated sugarcane plants. Plant Tissue Cult \& Biotech. 2006;16(1):25-29.

12. Comstock JC, Miller JD. Yield comparison: Disease free tissue cultures versus bud propagated planted sugarcane plants and healthy versus yellow leaf virus infected plants. Journal American Society Sugar Cane Technologists. 2004;24:31-40.

13. Cox M, Hogarth M, Smith G. Cane breeding and improvement. In: Hogarth M, et al, editors. Manual of cane growing. Bureau of Sugar Experimental Stations, Australia; 2000. p. 91-108.

14. Geetha S, Padmanabhan D. Effect of hormones on direct somatic embryogenesis in sugarcane. Sugar Tech. 2001;3(3):120-121. 